頸部皮下気腫にて発見された注腸検査後結腸穿孔の 1 例

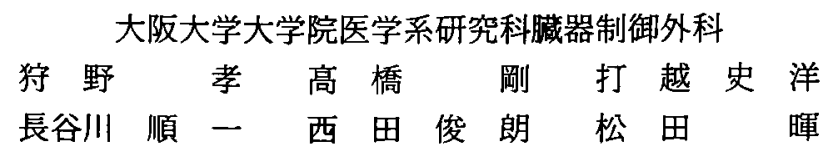

症例は67歳, 女性. 卵巣癌術後の化学療法施行中, 高 CEA 血症ならびに便潜血陽性を 指摘され，精査目的での注腸検查を施行した。直後の排便後より頸背部痛を訴え，単純 レントゲン検査にて頸部皮下気腫および気綖隔・気後腹膜を認めたため当科紹介となっ た. 医原性大腸穿孔と診断し緊急手術を施行した。開腹したところ, 横行結腸中央部付 近で腸間膜の対側が小腸腸間膜と疮着して扔り，同部て腸間膜内に穿孔，バリウムの漏 出を認めた。さらに腸間膜より，後腹膜腔さらに繸隔につながる air の噴出があったと考 えられた。結腸部分切除のうえ，双孔式人工肛門造設術を施行した。術後経過は良好で, 人工肛門閉鎖後 40 日目に退院となった. 注腸検查に合併した後腹膜腔気腫は稀であり, 報告例は検索し得る限りでは12例のみであった，われわれは, 術後の瘜着のため, 本来 遊離腸管である横行結腸より後腹膜腔に気腫を生じた函めて稀な症例を経験したため, これを報告する．

索引用語：頸部皮下気腫, 後腹膜穿孔, 注腸検查

\section{緒 言}

一般的に消化管の後腹膜穿孔は遊離腹腔内への穿孔 に比べ症状の出現が緩く, 診断が困難とされている. われわれは, 注腸造影検査施行後に頸部痛・皮下気 腫で発症した医原性大腸穿孔の１例を経験したので, 文献的考察を加え報告する.

$$
\text { 症例 }
$$

患者：67歳, 女性.

主訴：頸部痛, 腹痛.

既往歴：当院婦人科にて, 平成 15 年 4 月に卵巣癌に 対し子宮付属器切除, 骨盤内および大動脈周囲リンパ 節郭清, ダグラス窝腹膜播種部腹膜切除, 大網切除術 施行. 術後外来にてタキソール十カルボプラチンによ る化学療法を施行中であった。

家族歴：特記すべきことなし．

現病歴：平成15年12月上記フォロー中の検査にて CEA の軽度上昇ならびに便潜血陽性認めたため, 平成 16 年 2 月 9 日腹部精査目的に注腸検查を施行した。直

2005 年 4 月 4 日受付 2005 年 9 月 30 日採用 〈所属施設住所〉

T565-0871 吹田市山田丘 2-2
後の排便後より頸部痛を認め, 同時に上腹部痛も出現 した.

入院時現症：身長 $149 \mathrm{~cm}$, 体重 $51 \mathrm{~kg}$, 血圧 $112 / 56$ $\mathrm{mmHg}$ ，脈拍72回/分整。意識は清明．結膜に貧血・黄 㾝なし．胸部は聴診上異常所見なし．前頸部・心裔部 および上腹部に疼痛を認め，また触診にて頸部から前 胸部にかけて握雪感を認めた。

入院時検査成績 (表 1 )：血液検查では化学療法の影

表 1 入院時検査成績

\begin{tabular}{|c|c|c|c|c|}
\hline \multicolumn{2}{|l|}{ 血液学検查 } & \multicolumn{3}{|c|}{ 生化学検査 } \\
\hline WBC: & $2,130 / \mathrm{mm}^{3}$ & AST & 23 & $\mathrm{IU} / \mathrm{I}$ \\
\hline neu & $1,200 / \mathrm{mm}^{3}$ & ALT & 23 & $\mathrm{IU} / 1$ \\
\hline $\mathrm{RBC}:$ & $296 \times 10^{4} / \mathrm{mm}^{3}$ & LD & 294 & $\mathrm{IU} / 1$ \\
\hline $\mathrm{Hb}:$ & $9.0 \mathrm{~g} / \mathrm{dl}$ & $\mathrm{T}-\mathrm{Bil}$ & 0.7 & $\mathrm{mg} / \mathrm{dl}$ \\
\hline HCT : & $27.4 \%$ & TP & 5.4 & $\mathrm{~g} / \mathrm{dl}$ \\
\hline Plt : & $19.2 \times 10^{4} / \mathrm{mm}^{3}$ & Alb & 2.8 & $\mathrm{~g} / \mathrm{dl}$ \\
\hline PT (INR) & $75(1.18) \quad \%$ & BUN & 9 & $\mathrm{mg} / \mathrm{dl}$ \\
\hline \multirow[t]{3}{*}{ APTT } & 38 & $\mathrm{Na}$ & 138 & $\mathrm{mEq} / \mathrm{l}$ \\
\hline & & $\mathrm{K}$ & 3.9 & $\mathrm{mEq} / \mathrm{l}$ \\
\hline & & $\mathrm{Cl}$ & 102 & $\mathrm{mEq} / \mathrm{l}$ \\
\hline 腫痬マーカー & & CRE & 0.6 & $\mathrm{mg} / \mathrm{dl}$ \\
\hline CEA : & $7.0 \mathrm{ng} / \mathrm{dl}$ & CRP & $<0.2$ & $\mathrm{mg} / \mathrm{dl}$ \\
\hline CA19-9: & $<5.0 \mathrm{U} / \mathrm{ml}$ & & & \\
\hline
\end{tabular}




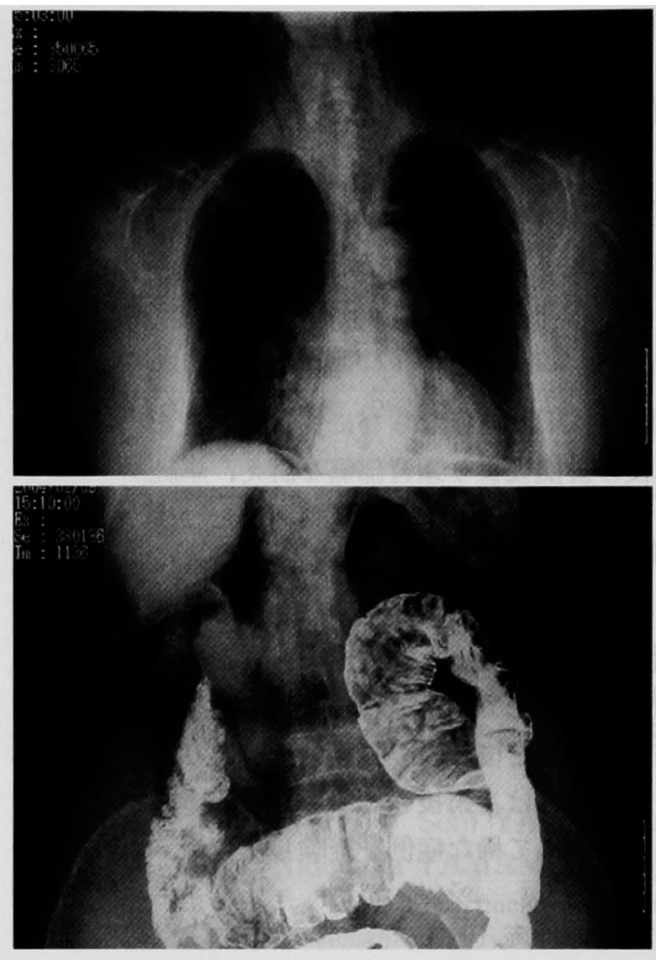

図 1 胸腹部単純レントゲン検査：澒部から肩にか けての皮下気腫および気繸隔, 後腹膜空へのガス 貯留像を認めた。

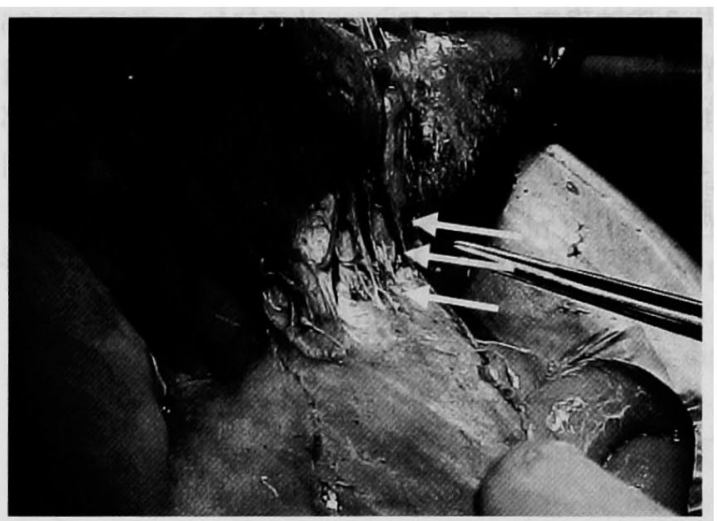

図 2 術中写真：横行結腸中央部にバリウムの軽度流出 を伴う穿孔部位を容易に確誌しえた。穿孔部横行結腸 は空腸腸間膜根部に疬着しており (矢印)，同部より腸 間膜内から後腹膜腔に気腫を認めた。

響により，白血球減少 $\left(\mathrm{WBC} 2,130 / \mathrm{mm}^{3}\right)$ と軽度貧血 （RBC 296万 $/ \mathrm{mm}^{3}, \mathrm{Hb} 9.0 \mathrm{~g} / \mathrm{dl}$, Ht 27.4\%) を認め たが，その他に異常所見は䜑められなかった，腫瘍マ 一カーはCEA $7 \mathrm{ng} / \mathrm{dl}$ と軽度高值であった。
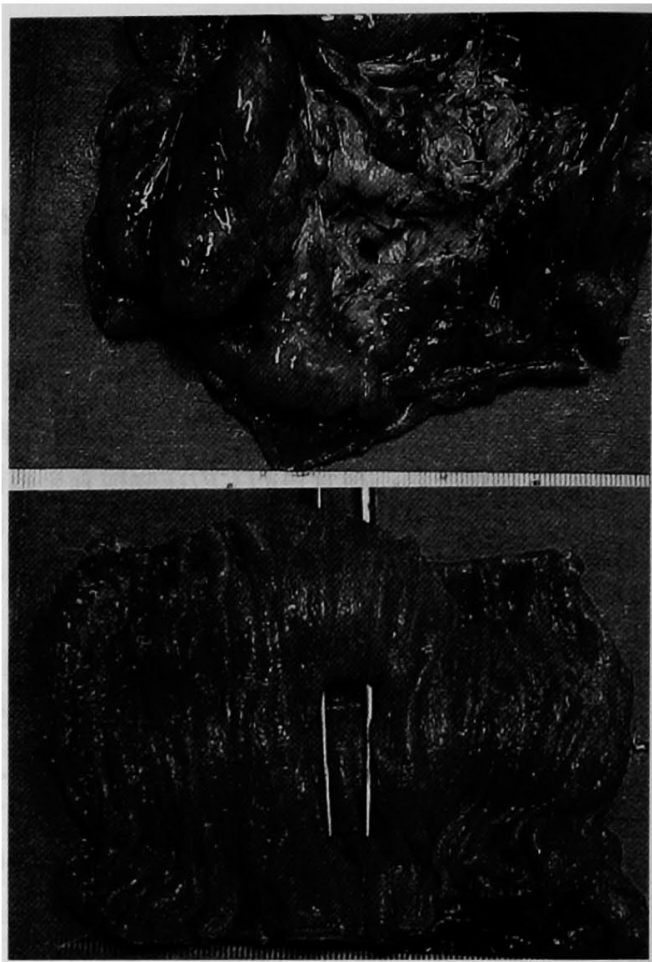

图 3 切除標本：結腸間膜付着部反対側に $1 \mathrm{~cm}$ 大 の穿孔部位を認め,その周囲の腸管外にはバリウム 漏出を認めた. 䕀室などの大腸病変は認めなかった。

画像所見：注腸造影検查では大腸に明らかな病変は 指摘されず，穿孔部位も明らかでなかった。また，検 查中に穿孔所見は認めなかった。発症時の胸腹部単純 $\mathrm{X}$ 線写真（図 1 ）では，頸部から肩にかけての皮下気 腫および気䋛隔，後腹膜腔へのガス貯留像を認めた。 以上の所見より医原性大腸穿孔と診断し，緊急手術を 施行した。

手術所見：開腹し腹哚内を観察したところ，横行結 腸中央部にバリウムの軽度流出を伴う穿孔部位（腸間 膜付着部の反対側）を容易に確認しえた（図 2 )。穿孔 部横行結腸は小腸腸間膜根部に病着しており，同部よ り腸間膜内から後腹膜腔に続く気腫を認めた，腹腔内 を洗浄後，結腸肝彎曲部を授動しつつ後腹膜腔・腸間 膜を開放した. 穿孔部を中心とした結腸部分切除を行 い，双孔式人工肛門造設術を施行した。

標出標本肉眼所見：摘出標本（図 3) では結腸間膜 付着部対側に $1 \mathrm{~cm}$ 大の穿孔部位を認め，その周囲の 腸管外にはバリウム漏出を認めた。

術後経過: 術後の経過は良好で, 術後 1 力月て人工 肛門は閉鎖。術後40日目に退院した。 
表 2 注腸検査後の後腹膜穿孔報告例

\begin{tabular}{|c|c|c|c|c|c|}
\hline 報告者 & 年齢/性 & 症状 & 穿孔部位 & 治療 & 転㷌 \\
\hline Brown" & $58 / \mathrm{M}$ & $\begin{array}{l}\text { 呼吸困難 } \\
\text { 䫫部皮下気程 }\end{array}$ & 㨁腸 & 保存的 & 数日で気腫消失 \\
\hline Goldberg ${ }^{5)}$ & $63 / \mathrm{M}$ & $\begin{array}{l}\text { 発熱 } \\
\text { 皮下気腫 }\end{array}$ & 不明 & 保存的 & 2 週間で気尰消失 \\
\hline Spiro' & $70 / F$ & $\begin{array}{l}\text { 呼吸困難, ショック } \\
\text { 頻部皮下気腫 }\end{array}$ & $\begin{array}{l}\text { 直腸 } \\
\text { 肛門より } 6 \mathrm{~cm} \text { 口側 }\end{array}$ & $\begin{array}{l}\text { ドレナージ術 } \\
\text { 人工肛門造設術 }\end{array}$ & 3 週間後に退院 \\
\hline Lorinc $^{7)}$ & $63 / \mathrm{M}$ & なし & 直腸 & 人工肛門造設術 & 释過良好 \\
\hline Lorinc $^{7}$ & $68 / \mathrm{M}$ & 陰毒気腫 & $\begin{array}{l}\text { 直腸 } \\
\text { 歯状線直上 }\end{array}$ & 保存的 & 12日間で退院 \\
\hline Brunton $^{8)}$ & $68 / F$ & $\begin{array}{l}\text { 皮下気腫 } \\
\text { 腹痛 背部痛 }\end{array}$ & 不明 & 保存的 & 14日間で退院 \\
\hline Geigle $^{9 !}$ & $71 / \mathrm{M}$ & $\begin{array}{l}\text { 発熱 } \\
\text { 皮下気腫 }\end{array}$ & 直腸 & ドレナーシ & 9 日間で退院 \\
\hline Pyle & $67 / \mathrm{M}$ & $\begin{array}{l}\text { 前胸部皮下気腫 } \\
\text { 前胸部痛 }\end{array}$ & $\begin{array}{l}\text { 直腸 } \\
\text { 肛門より } 11 \mathrm{~cm} \text { 口側 }\end{array}$ & 保存的 & 10日間で退院 \\
\hline Beerman"1 & $72 / \mathrm{M}$ & 発熱 & S 状結腸 & S 状結腸切除 & 術後経過良好 \\
\hline Peterson ${ }^{12)}$ & $79 / \mathrm{F}$ & なし & 不明 & $\begin{array}{l}\text { ドレナージ術 } \\
\text { 人工肛門造設術 }\end{array}$ & $\begin{array}{l}\text { 人工肛門の状態で } \\
\text { 11日間で退院 }\end{array}$ \\
\hline Tadros $^{13)}$ & $84 / F$ & $\begin{array}{l}\text { 前胸部痛 } \\
\text { 形新部皮下気㯵 }\end{array}$ & $\begin{array}{l}\text { 直腸 } \\
\text { 肛門より } 6 \mathrm{~cm} \text { 口側 }\end{array}$ & 保存的治療 & $\begin{array}{l}\text { 数日で気腫消失 } \\
1 \text { カ月で退院 }\end{array}$ \\
\hline 自験例 & $67 / F$ & 䁰部痛 腹部痛 & 横行結腸 & $\begin{array}{l}\text { ドレナージ術 } \\
\text { 人工肛門造設術 }\end{array}$ & $\begin{array}{l}\text { 人工肛門閉鎖後 } \\
\text { 退院 }\end{array}$ \\
\hline
\end{tabular}

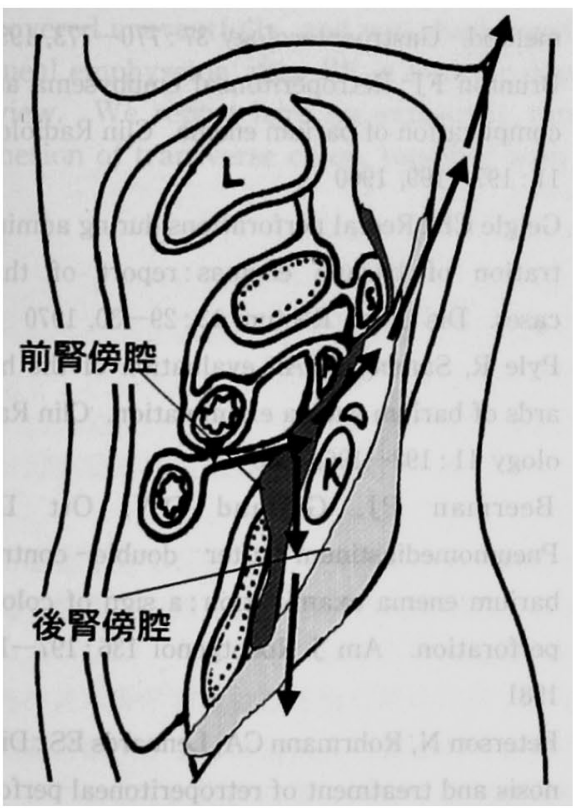

図 4 腸管穿孔のシェーマ：斜線は前腎傍 䏶, 点線は後腎傍腔である.癁着のため, 横行結腸が, 小腸腸間膜と瘾着を示し同部 で穿孔し，小腸腸間膜内へ流出した。さら に矢印で示す如く小腸間膜根部・前腎傍控 へ気腫が広がった。

\section{考察}

注腸造影検査において，大腸穿孔は稀ではあるが， 重篤な合併症である. Cordone ら”は,アメリカにおい て毎年500例以上の穿孔例があると報告しており,鳥越 $ら^{2)}$ は自施設検査 4,200 例中の 2 例 $(0.04 \%)$ に認めた と報告している.チューブ先端による機械的損傷と， 洗浄液やバリウムや空気の注入による腸管内圧の上昇 が原因と考えられる．しかし穿孔時には，直腸や S 状 結腸から遊離腹腔内人穿孔することが圧倒的に多

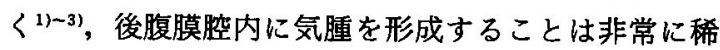
である。

注腸検査時に生じた後腹膜への穿孔症例は，われわ れが検索しえた限りでは自験例を含めて12例が報告さ れている(表 2 )．穿孔部位は，本症例を除きいずれも 肛門に近く圧がかかりやすいと考えられる直腸，S 状 結腸で生じている. 外科的治療がその半数についてな され，予後はいずれも良好なものとなっている。

腹膜外腔は，感染に対する反応が弱くその臨床症状 は非特異的である．穿孔部から流出したガスが後腹膜 腔内を上方に移動すると本症例の如く頸部・前胸部痛 が生じ, 下方に移動すると腰痛や下肢痛を生じると考 
えられる．同時に広範囲の皮下気腫を伴うことが多い ものの，前処置として機戌的洗浄が行われており污染 が比較的軽度にとどまっているためか, 表 2 の如く自 験例を含むいずれも良い転帰となっている，ただし， 診断が遅れたため，後腹膜の粗な組織を伝い炎症が急 速に㹡大進展し，血圧低下や四肢冷感などのショック 症状を呈するに至った症例も報告到されて扔り，適切 な抗生刘投与と開腹ドレナージ術が必要である。下部 消化管穿孔では上部消化管に比べ, Escherichia coli, Klebsiera, Proteus, Bacteroides spp.などのグラム陰 性菌や嫌気性菌の混合感染を生じ難治例も多く, 第 3 世代のセフェム系やカルパペネム系抗生郕が選択され $3^{14)-17}$. 炎症が広く波及し，後腹膜炎に至った症例で は人工肍門造設術が必要となる。広がった皮下気腫は， 数日から 2 週間程度の観察でほ浔消失すると報告され ており ${ }^{12)}$, 気腫のみの部位については原則経過観察の みでよいと思われる，本症例では，注腸検查直後の発 症ですぐに加療を開始することができたものの，化学 療法施行中に伴う易感染状態であり，保存的治療では 後腹膜炎を発症する危険性が高いと判断した。積極的 に開腹術を施行し，バリウムを伴う気腫を認めた腸間 膜を開放, 洗净ドレナージ術の後, 腸管切除, 人工肛 門造設術を行った。術中の污染状況から気縦隔, 頸部 皮下気腫は保存的治療コントロール可能と判断し, 良 好な結果を得た。

後腹膜は，その局在部位にて前腎傍腔・腎周囲腔・ 後腎傍空の 3 つに分けることができる ${ }^{18) 19}$. 前腎傍腔 には十二指腸・上下行結腸・脾荿が存在しており, 気 腫の原因として十二指腸および上下行結腸穿孔や気腫 性脺炎などが考えられる。本症例の如く前腎傍腔内気 腫の原因として, 術前は上行結腸ないし下行結腸より の後腹膜への穿孔を考えたが，実際は遊離腹腔内に存 在する横行結腸の穿孔による極めて稀なケースであっ た. 大網切除を伴う婦人科癌術後の癒着のため, 横行 結腸が，小腸腸間膜と癒着を示し同部で穿孔し，ガス が腹腔内でなく腸間膜内へ流出したと考えられた（図 $4)$.さらに矢印で示す如く小腸間膜根部・前腎傍腔を 経由し，縱隔および頸部皮下気腫を形成するに至った と考えられた。

\section{おわりに}

以上, 頸部皮下気腫にて発症した注腸検查後結腸穿 孔の 1 例を経験したため, 文献的考察を加えて報告し た.
文献

1) Cordone RP, Brandeis SZ, Richman $H$ : Rectal perforation during barium enema. Dis Colon Rectum $31: 563-569,1988$

2）鳥越敏明, 國崎忠臣, 菅村洋治他: Iatrogenic Colonic Perforationの検討. 外科 54:781783, 1992

3) Fry RD, Shemesh EI, Kodner IJ, et al : Perforation of the sigmoid colon during barium-enema examination. Management and prevention. Dis Colon Rectum 32 : 759-764, 1989

4) Brown S, Fine A : Diffuse emphysema following a double contrast enema. Radiology 37 : 228-229, 1941

5) Goldberg L:Surgical emphysema following double contrast enema. Case report. Treat Serv Bull $6: 25-28,1951$

6) Spiro RK : Perforation of the rectum following barium enema. Am J Gastroenterology $30: 540$ $-543,1958$

7) Lorinc P, Brahme F : Perforation of the colon during examination by the double contrast method. Gastroenterology $37: 770-773,1959$

8) Brunton FJ : Retroperitoneal emphysema as a complication of barium enema. Clin Radiology 11 : 197-199, 1960

9) Geigle CF : Rectal perforations during administration of barium enemas: report of three cases. Dis Colon Rectum $13: 29-30,1970$

10) Pyle R, Samuel E: An evaluation of the hazards of barium enema examination. Clin Radiology $11: 192-196,1960$

11) Beerman PJ, Gelfand DW, Ott DJ : Pneumomediastinum after double-contrast barium enema examination : a sign of colonic perforation. Am J Roentgenol 136 : 197-198, 1981

12) Peterson N, Rohrmann CA, Lennards ES : Diagnosis and treatment of retroperitoneal perfora. tion complicating the double-contrast bariumenema examination. Radiology $144: 249-252$, 1982

13) Tadros $S$, Watters JM : Retroperitoneal perforation of the rectum during barium enema 
examination. Can J Surg $31: 49-51,1988$

14）桜井 修, 高橋愛樹, 大野勝之：下部消化管穿孔 性腹膜炎における嫌気性菌の関与。日外感染症研 $2: 84-88,1990$

15）石川 周, 由良二郎：腹腔内感染症の抗生物質療 法. 外科治療 $57: 417-424,1987$

16）岩井重富, 坂部 孝: 嫌気性感染症. 外科診療 $30: 1659-1667,1987$

17）福島亮治, 冲永功太：術後重症腹腔内感染症への
対応. 臨外 58:47-52, 2003

18) Mayer MA : The extra peritoneal spaces : Normal and pathologic anatomy. Dynamic radiology of the abdomen, $3^{\text {rd }}$ ed, Springer-Verlag, New York, 1988, p179-278

19）松木 充, 井上 豊, 山崎紘一地: 後腹膜気腫を きたした非外傷性大腸穿孔の 2 例. 臨放線 40 ： $1067-1070,1995$

\title{
A CASE OF COLONIC PERFORATION AFTER BARIUM ENEMA DISCOVERED BY SUBCUTANEOUS EMPHYSEMA IN THE NECK
}

\author{
Takashi KANO, Tsuyoshi TAKAHASHI, Fumihiro UCHIKOSHI, \\ Junichi HASEGAWA, Toshiro NISHIDA and Hikaru MATSUDA \\ Department of Surgery, Osaka University Graduate School of Medicine
}

A 67-year-old woman who underwent adjuvant chemotherapy for ovarian cancer, complained of neck and back pain immediately after barium enema. A plain chest X-ray revealed that she had developed subcutaneous emphysema in the neck, mediastinum and retroperitoneum. An emergent operation was performed under a diagnosis of iatrogenic colonic perforation, and it was found that the air and barium diffused into the retroperitoneal space through the adhesion of transverse colon to mesentery. Partial colectomy and the creation of transverse colostomy was performed. The patient recovered uneventfully, and was discharged on the 40th POD after closure of the stoma. The retroperitoneal emphysema after $\mathrm{BE}$ is a rare complication and 12 cases have been reported as far as we could review. We report here an extremely rare case of retroperitoneal emphysema after $\mathrm{BE}$ due to the adhesion of transverse colon, together with a review of the literature. 